\title{
A List of Important Honeybee Nectariferous and Polleniferous Plant Species in the West Bank Governorates, Palestine
}

\author{
Imadeddin Albaba \\ P. O. Box 64, Halhul, Hebron Dist, West Bank 741, Palestine
}

\begin{abstract}
The main goal of this study is to provide information about the foraging value of a number of specific plant species for honeybees in Palestine, since one of the limiting factors of Palestine's apiculture industry is the unpredicted seasonality in the blooming phenology of nectariferous and polleniferous plant species. This limiting factor can be overcome by increasing and diversifying the population of bee forage plant species throughout man made plantations. In this survey, a combination of literature and field surveys were used in order to identify and compile a list of plant species, which are of importance for fulfilling the honeybee's needs of nectar and pollen. The study was conducted through bi-weekly visit to a numbers of randomly selected sites located in some nature reserves and agricultural fields, within the West Bank Governorates. A total of 143 nectariferous and polleniferous plant species, belonging to 37 families, were identified through direct observation of foraging bees, and/or through literature survey. The dominant families are Compositae with 27 (18.8\%) belonging species, followed by Lamiaceae family with 24 (16.7\%) belonging species, then followed by Boraginaceae family with 8 (5.5\%) belonging species and then followed by other families. The identified plant species was grouped into pollen, nectar and both pollen and nectar sources plant species. The polleniferous plant species group counted 17 which is equivalent to $11.8 \%$; the nectariferous plant species group counted 29 which is equivalent to 20.2\%; and the third groups of plant species that have been visited by bees for collecting both pollen and nectar counted 97 , which is equivalent to $68 \%$. The chronologies of the blooming plant species were also recorded. It was concluded that any of the studied locations can be profitably utilized for commercial and or large scale beekeeping, if the important limiting factor can be overcome by increasing and diversifying the population of bee forage plant species throughout man made plantations. The paper provides information on the wild and cultivated nectariferous and polleniferous plants that are important for the bees in the West Bank Governorates, Palestine.
\end{abstract}

Key words: Diversity, honeybees, nectariferous, polleniferous, Palestine.

\section{Introduction}

Flowers are the mainstay of bee's life. Honeybee workers make thousands of visits to flowers in order to collect nectar and pollen. Flowering plants of several plant families are blooming at different time intervals of the year [1]. Depending upon the soil type, climatic factors and the habitat of the vegetation, the time of the blossoming may change for even the same nectar plants [2]. Sound information on duration of flowering and blooming time is essential for proper

Corresponding author: Imadeddin Albaba, M.Sc., research fields: agriculture, environment and wildlife. E-mail: beesresearch@gmail.com. beekeeping management [3]. The practice of beekeeping is not only depends on the better strain of honeybees but also on abundance and occurrence of pollen and nectar sources within the surrounding area of an apiary [4]. The good knowledge of the diversity, density and blooming chronologies of nectariferous and polleniferous species are prerequisite and essential for guiding beekeepers in the choice of the best suitable sites for locating their apiaries and subsequently enhancing the efficiency of beekeeping industry and successful beekeeping. Such enhancement may enable beekeepers to harvest a good yield of honey and other bee products, and increase their own financial profits. 
Literature survey showed that information on local bee forage plants was compiled by several studies conducted by several scientists, like Refs. [1, 5-13].

In the book, Free [1] mentioned that pollen are more efficiently collected and distributed by mechanical means (by insects or wind current) on crop plants which require cross pollination. The author also arranged crops needing pollination by various pollinator insects in general and those plant families pollinated by honeybees, notably Papilionaceae and Rosaceae. Zohary [5] includes the whole area of the West Bank and the Gaza Strip in his flora palestinae multi volume books, which have updated nomenclature, distribution and habitat data for 2,700 species. Fahn [6] identified nectaries of honey plants in the land of Israel, their structure and the effects of ecological factors on nectar secretion. Gindel [7] studied the acclimation of Eucalyptus during 1935-1951 in Israel as a potential source of food rewards for honeybees. Lupo and Eisikowitch [8] concluded that Eucalyptus erythrocoris is important source of nectar and pollen for honeybees in Israel. In their evaluation study, Dag et al. [9] studied the economic values of bee forage plants planted in Israel. Dag et al. [10] studied the pollen sources for honeybees colonies in Israel. Reves [11], the author of a guide to Eucalyptus species growing in Israel, had shown the importance of different species grown for beekeeping purposes. Tamar and Shmida [12] compiled a list of 266 local wild plant species that have high food potential for honeybees in the neighboring state of Israel. Albaba [13] in previous study showed that a total number of 393 species of plants were identified with the recorded species belonging to 57 families, as potential forage plants for bees in the West Bank, Palestine.

The results of identification of the plant species collected in the investigated sites, their systematic, phenology and other information have followed the Israeli website called the Flora of Israel, which is powered by the Hebrew University in addition to $\mathrm{Al}$ Sheikh and Salman [14].

\section{Material and Methods}

\subsection{Study Site}

The West Bank is mostly located on the Central highlands of Palestine, just above the Jordan valley. It is composed of four climatically differentiated zones. The semi-coastal zone, which is a narrow strip extending at 100-300 $\mathrm{m}$ above sea level, in the North-Northwest corner, comprises of Jenin, Qalqilia and Tulkarem districts; soil is mostly alluvial and loam; the annual rainfall is $600 \mathrm{~mm}$. The second climatic zone is Central highlands, which is mountainous rock and hilly area rising up $1,027 \mathrm{~m}$ above sea level, includs area from Jenin Southwards until Hebron district and receives annual rainfall around $400 \mathrm{~mm}$. The third zone is Eastern slope zone, comprises of steep mountains with little rainfall (150-300 mm) and represents the semi-desert climate, as transitional area between Mediterranean and desert. The fourth climatic zone is the Jordan valley and lies $390 \mathrm{~m}$ below sea level; the soil is brackish with high content ratio of sodium [15].

\subsection{Survey of Nectariferous and Polleniferous Species}

A combination of literature and field surveys were used in order to identify and compile a list of 143 plant species, which are of importance for fulfilling the honeybee's needs of nectar and pollen. The study was conducted through bi-weekly visit to the selected sites located in some nature reserves or agricultural fields, which was randomly selected in the West Bank Governorates. In every site visit, four line transects of $1,000 \mathrm{~m}$ in length each, were selected and stationed on two separate points in each surveyed site. The start and end of each transect were marked with the national flags to enhance visibility. While moving on the transects each five steps interval, flowering plants found within $2 \mathrm{~m}$ radius, were visited and observed for the presence and foraging activities of honeybees within a predetermined period of 10 min. Plants were scored as bee foraging species, when at least three 
honeybees had visited and foraged on the flowers within the observation period [16]. Camera shots were used to prove the honeybee's presence and identification of the plant species.

The literature survey revealed a preliminary list of plants diversity as potential forage plants for bees in the West Bank, Palestine. It was compiled based on field survey and literature survey of many existing references, such as Refs. [3-5, 7, 10, 12, 14, 16, 17]. Plant identification, phenology and other information were obtained basically from Ref. [5], flora of Israel web [18] and the preliminary checklist and ecological data—base of plants of the West Bank [14].

\section{Results and Discussion}

The study area (the West Bank) is mostly located on the Central highlands of Palestine, just above the Jordan valley, whereas natural forest, agricultural fields and irrigated crops are found. Annex 1 lists 143 species from the native flora of Palestine that were identified as bee forage plants out of an initial list of 393 potential plants. The table also reports these species' main food rewards and their blooming period in Palestine. Based on the results of this study, a total of 143 nectariferous and polleniferous plant species, belonging to 37 families (Fig. 1), were identified through direct observation of foraging bees, and/or through literature survey.
The results have shown that the most important nectariferous and polleniferous plants species are the representatives of family Compositae (Achillea falcata, Achillea fragrantissima, Achillea santolina, Carthamus glaucus, Carthamus nitidus, Carthamus tenuis, Centaurea hyalolepis, Centaurea iberica, Centaurea lanulata, Centaurea pallescens, Centaurea verutum, Chiliadenus iphionoides, Crupina crupinastrum, Onopordum alexandrinum, Onopordum blancheanum, Onopordum carduiforme, Onopordum cynarocephalum, Senecio joppensis, Senecio vernalis, Silybum marianum, Cynara syriaca, Dittrichia graveolens, Dittrichia viscosa, Echinops gaillardotii, Echinops philistaeus, Eupatorium cannabinum, Notobasis syriaca), followed by the representatives of family Lamiaceae (Ballota undulata, Coridothymus capitatu, Lamium moschatum, Lavandula stoechas, Mentha sp., Micromeria fruticosa, Prasium majus, Rosmarinus officinali, Salvia fruticosa, Salvia hierosolymitana, Salvia indica, Salvia judaica, Satureja thymbra, Sideritis perfoliata, Sideritis pullulan, Stachys distans, Teucrium creticum, Teucrium divaricatum, Teucrium scordium, Trifolium fragiferum, Trifolium palaestinum, Trifolium purpureum, Trifolium repens, Trifolium resupinatum), then followed by the representatives of family Boraginaceae (Alkanna strigosa, Cynoglossum creticum, Echiochilon fruticosum, Echium angustifolium,

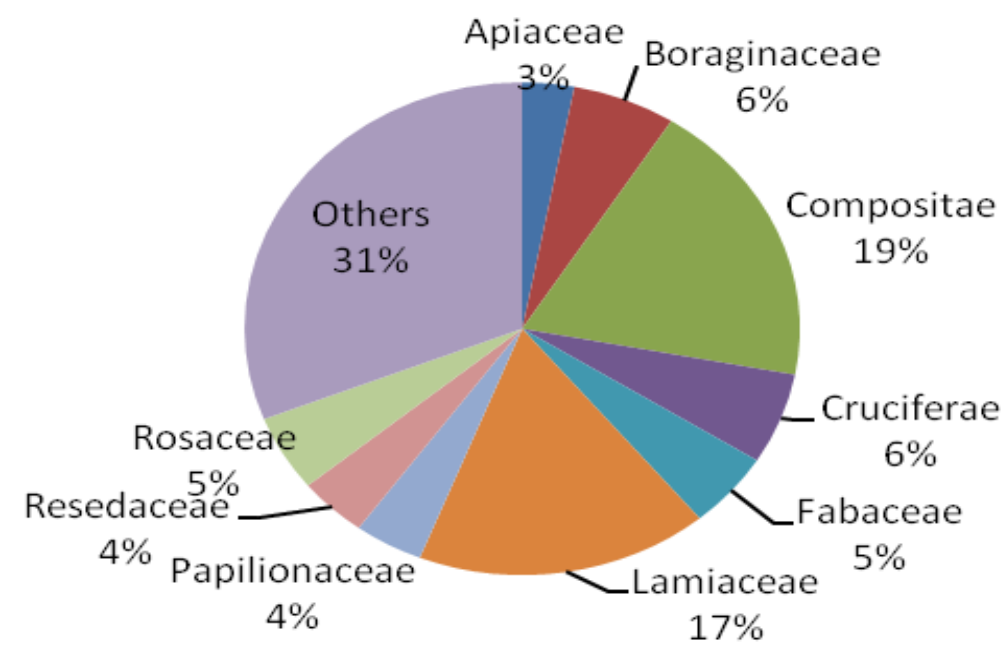

Fig. 1 Family wise distribution in percentage of nectariferous and polleniferous plant species. 
Echium glomeratum, Echium judaeum, Echium plantagineum, Moltkiopsis ciliata), and followed by other families representatives as listed in Annex 1.

The identified plant species was grouped into three groups based on their food rewards: a group of pollen source plants species, a group of nectar source plants species and the third group of both pollen and nectar sources plant species. The results have shown the dominance of the plant species which have been visited for collecting both pollen and nectar, counted 97 (68\%). The pollen source plant species counted 17 (12\%) and the nectar source species were 29 (17\%). Flower morphology and the low pollen productivity of nectariferous plants may affect the quantitative participation of pollen as a food rewards sources to attract bees. Some species of Fabaceae family (Medicago sativa, Melilotus albus) have a secondary period of flowering in late autumn or in summer, which is very important for supplying the honeybees with nectar and pollen during the dry season here in Palestine (Fig. 2).

Column five of Annex 1 provides a classification of the survey species according to their main food elements to honeybees (nectar $(\mathrm{N})$, pollen $(\mathrm{P})$ or both $(\mathrm{N}+\mathrm{P})$ ). This classification is based on qualitative observations of honeybees behavior and does not express the quantity of nectar or pollen produced per plant or collected by bees. The chronology of main period of blooming plant species were defined as in Fig. 3. The peak blooming period was recorded in April, followed by May, then by March and then by June, etc..

Fig. 3 showed that the months January and December are characterized by a low number of flowering polleniferous and nectariferous plants. This study emphasizes the importance of polleniferous and nectariferous plants for honeybees in the West Bank

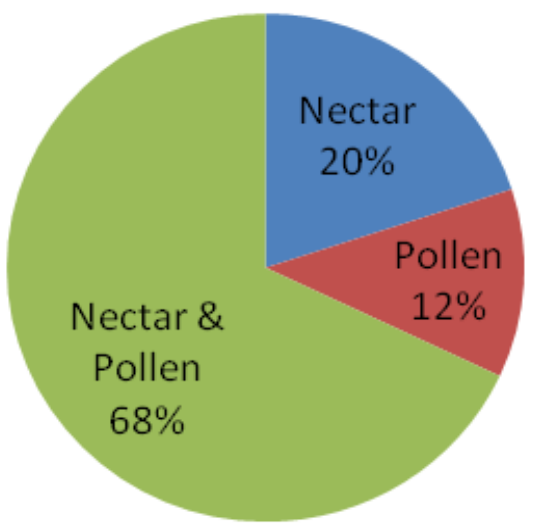

Fig. 2 Food rewards wise distribution in percentage of nectariferous and pollenferous species visited by honeybees workers.

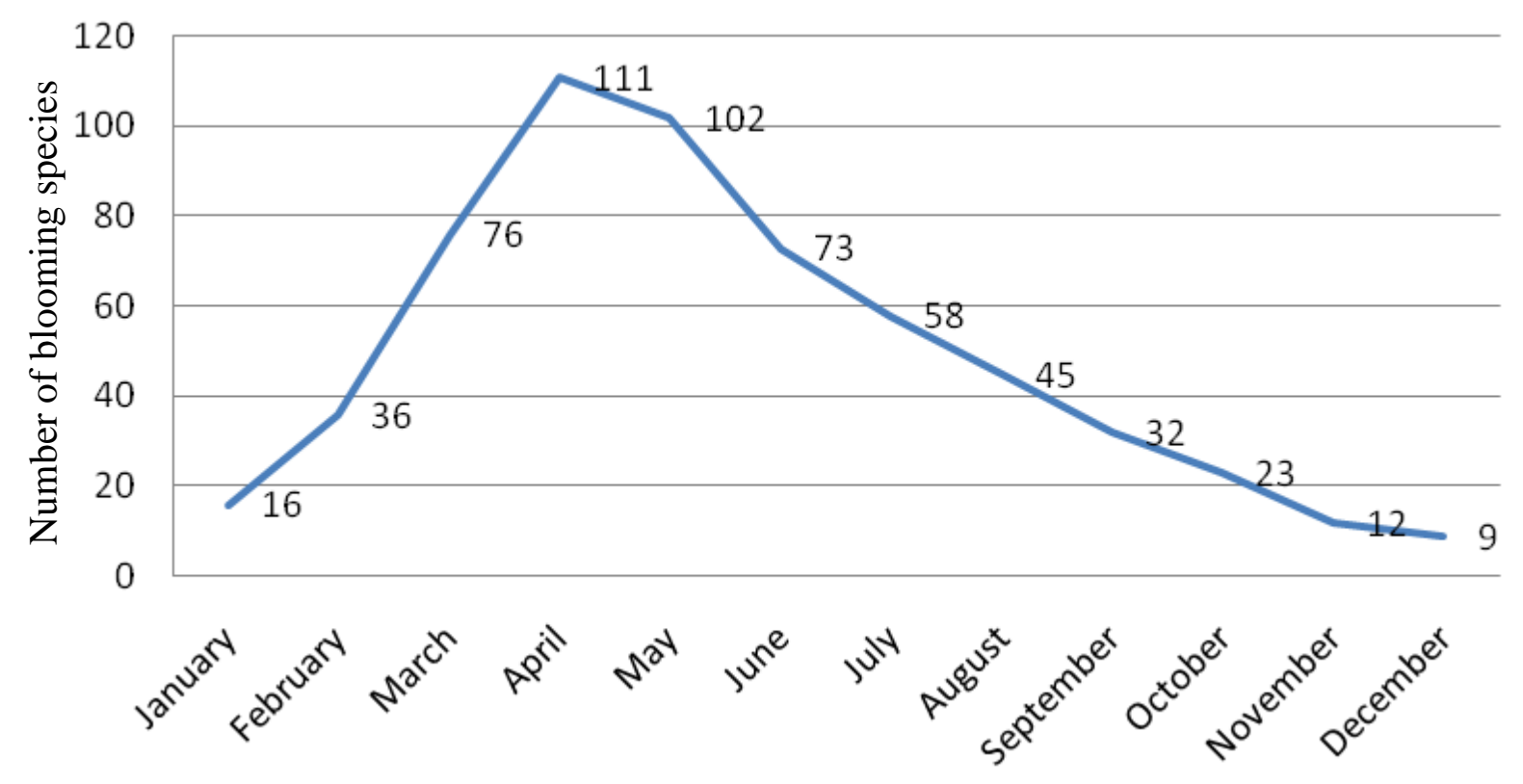

Fig. 3 Number of blooming species throughout months. 
Governorates, Palestine. Their findings demonstrate the fluctuations in pollen and nectar availability for bees throughout the months of the year, which will subsequently affect negatively the honey yields and pollination services. These finding are in agreement with many regional and international studies. The listed plant species are of importance for securing food of honeybees and also contribute to the beautiful landscape. Considering its environmental importance, these plant species are recommended to be protected by competent agencies of the Palestinian authority as well as by the surrounding countries.

\section{Conclusions}

The author's findings have led to some conclusions about the local flora visited by honeybees for nectar and pollen grains. A hundred and forty three taxa have been established in the study of importance for the honeybees in Palestine.

It could be concluded that any of the studied locations can be profitably utilized for commercial or large scale beekeeping, if the important limiting factor can be overcome by increasing and diversifying the population of bee forage plant species throughout man made plantations. The results and subsequent conclusion are in agreement with many regional studies.

Six species of the surveyed plants (Hedera helix, Moltkiopsis ciliate, Senecio vernalis, Maresia pulchella, Sinapis alba and Leucophyllum frutescens) produce pollen and nectar, and have long blooming period. Therefore, the author recommend their conservation and planting if possible as pollen and nectar sources, in combination with other plants that can serve as sources of food elements for honeybees in Palestine

\section{References}

[1] Free, J. B. 1970. Insect Pollination of Crops. London: Academic Press, 544.

[2] Rodinov, V., and Shabanshov, V. 1986. The Fascinating World of Bees. Moscow: Mir Publishers, 35-75.
[3] Kumar, R., Rajput, G. S., Mishra, R. C., and Agrawal, O. P. 2013. "A Study on Assessment of Duration of Dearth Period for Honeybees in Haryana, India.” Munis Entomology and Zoology 8 (1): 434-7.

[4] Akrathanakal, P. 1987. "Beekeeping in Asia.” FAO, United Nations. Accessed April 7, 2015. http://www.fao.org/docrep/x0083e/x0083e00.HTM.

[5] Zohary, M. 1966. Flora Palaestina. Jerusalem: The Israeli Academy of Science and Humanities.

[6] Fahn, A. 1948. The Nectarines of Honey Plants in the Land of Israel: Their Structure and the Effects of Ecological Factors on Nectar Secretion. Rehovot: Hebrew Apiculturists Society.

[7] Gindel, Y. 1951. The Eucalyptus in Israel: A Study of Its Acclimation during 1935-1951. Rehovot, Israel: Agricultural Research Station.

[8] Lupo, A., and Eisikowitch, D. 1987. "Eucalyptus erythrocorys: A Honey and Pollen Plant.” Hassade 77: 2363-7. (in Hebrew)

[9] Dag, A., Regev, A., and Bar-Yossef, Y. 1998. “The Economic Values of Planted Bee Forage Plants.” Ecology and Environment 4: 234-5. (in Hebrew)

[10] Dag, A., Rotem, T., and Sela, N. 1993. "Finding Pollen Sources for Bee Colonies.” Hassade 63: 1286-9. (in Hebrew)

[11] Reves, Y. 2004. A Guide to Eucalyptus Species Growing in Israel. Rehovot, Israel: Novell Publishers. (in Hebrew)

[12] Tamar, K., and Shmida, A. 2009. "An Evaluation of Israeli Forestry Trees and Shrubs as Potential Forage Plants for Bees.” Israel Journal of Plant Sciences 57 (1-2): 49-64.

[13] AlBaba, I. 2013. “A Preliminary Survey of West Bank Plants Diversity as Potential Foragae Plants for Bees in West Bank-Palestine.” Pro. J. of Agr. Sci. Res. 1 (3): 57-63.

[14] Al-Sheikh, B., and Salman, M. 2000. Preliminary Checklist and Ecological Data-Base of Plants of the West Bank. Jerusalem: Al-Quds University.

[15] Palestinian Institute for Arid Land and Environmental Studies (PIALES). 1996. A Preliminary Investigation of Biodiversity in Palestine: Problems and Prospects. Hebron, Palestinian Territories: PIALES.

[16] The Jerusalem Botanic Gardens. 2015. "Flora of Israel." Accessed April 30, 2015. http://www.botanic.co.il/ Pages/Show/106.

[17] Deodikar, G. B., and Thakar, C. V. 1966. "Utilization and Improvement of the Local Floras as Bee Pasturage.” Indian Bee J. 28: 11-5.

[18] Zohary, M. 1947. "The Honey Plants of the Land of Israel.” Publication of the Agricultural Research Station, Rehovot, Israel. Accessed April 7, 2015. http://www.honey.org.il/lit/zohary/plants.htm. (in Hebrew) 
Annex 1 A list of important honeybee nectariferous and polleniferous plant species of the West Bank Governorates, Palestine.

\begin{tabular}{|c|c|c|c|c|c|}
\hline No. & Spp. scientific name & Family name & Spp. English name & Food elements & Blooming months \\
\hline 1 & Asphodeline lutea & Liliaceae & Yellow Asphodel & P \& N & March-May \\
\hline 2 & Asphodelus aestivus & Liliaceae & Asphodel & $P \& N$ & February-May \\
\hline 3 & Acer obtusifolium & Aceraceae & Syrian Maple & $P \& N$ & March-May \\
\hline 4 & Ammi visnaga & Apiaceae & Toothpick & $\mathrm{P}$ & April-August \\
\hline 5 & Cuminum cyminum & Apiaceae & Cumin & $P \& N$ & March-April \\
\hline 6 & Eryngium creticum & Apiaceae & Field Eryngo & $P \& N$ & May-August \\
\hline 7 & Eryngium glomeratum & Apiaceae & Sea Holly & $P \& N$ & May-September \\
\hline 8 & Eryngium maritimum & Apiaceae & Sea Holly & $P \& N$ & April-August \\
\hline 9 & Hedera helix & Araliaceae & Ivy & $P \& N$ & January-December \\
\hline 10 & Scilla hyacinthoides & Asparagaceae & Hyacinth Sqill & $P \& N$ & February-April \\
\hline 11 & Alkanna strigosa & Boraginaceae & Strigose Alkanet & $\mathrm{N}$ & March-June \\
\hline 12 & Cynoglossum creticum & Boraginaceae & Blue Hound’s Tongue & $\mathrm{N}$ & April-May \\
\hline 13 & Echiochilon fruticosum & Boraginaceae & Bushy Bugloss & $\mathrm{N}$ & March-June \\
\hline 14 & Echium angustifolium & Boraginaceae & Hispid Viper's-bugloss & $P \& N$ & March-August \\
\hline 15 & Echium glomeratum & Boraginaceae & Tall Viper’s-bugloss & $P \& N$ & March-June \\
\hline 16 & Echium judaeum & Boraginaceae & Judean Viper's-bugloss & $P \& N$ & March-April \\
\hline 17 & Echium plantagineum & Boraginaceae & Purple Viper's Bugloss & $P \& N$ & January-April \\
\hline 18 & Moltkiopsis ciliata & Boraginaceae & Callous-leaved Gromwell & $\mathrm{N}$ & December-August \\
\hline 19 & Ceratonia siliqua & Caesalpiniaceae & Carob tree & $P \& N$ & July \\
\hline 20 & Cercis siliquastrum & Caesalpiniaceae & Cercis & $\mathrm{N}$ & February-May \\
\hline 21 & Capparis aegyptiaca & Capparaceae & Egyptian Caper & $P \& N$ & March-August \\
\hline 22 & Capparis sicula & Capparaceae & Caper & $P \& N$ & April-October \\
\hline 23 & Capparis spinosa & Capparaceae & Spiny Caper & $P \& N$ & March-August \\
\hline 24 & Scabiosa palaestina & Caprifoliaceae & Scabious & $P \& N$ & March-May \\
\hline 25 & Scabiosa prolifera & Caprifoliaceae & Prolific Scabious & $P \& N$ & March-May \\
\hline 26 & Cistus incanus & Cistaceae & Hairy Rockrose & $\mathrm{P}$ & March-June \\
\hline 27 & Helianthemum vesicarium & Cistaceae & Pink Sun-rose & $P \& N$ & January-May \\
\hline 28 & Achillea falcate & Compositae & Sulphur-colored Milfoil & $P \& N$ & April-May \\
\hline 29 & Achillea fragrantissima & Compositae & Lavender Cotton & $P \& N$ & March-May \\
\hline 30 & Achillea santolina & Compositae & Woolly Yarrow & $P \& N$ & March-May \\
\hline 31 & Carthamus glaucus & Compositae & Glaucous Star Thistle & $N \& P$ & May-August \\
\hline 32 & Carthamus nitidus & Compositae & Smooth Distaff thistle & $N \& P$ & April-August \\
\hline 33 & Carthamus tenuis & Compositae & Safflower & $N \& P$ & May-September \\
\hline 34 & Centaurea hyalolepis & Compositae & Centaury-thistle & $N \& P$ & March-June \\
\hline 35 & Centaurea iberica & Compositae & Spanish Centaury-thistle & $N \& P$ & April-July \\
\hline 36 & Centaurea lanulata & Compositae & Centaury-thistle & $N \& P$ & January-May \\
\hline 37 & Centaurea pallescens & Compositae & Centaury & $N \& P$ & April-August \\
\hline 38 & Centaurea verutum & Compositae & Centaury-thistle & $N \& P$ & May-July \\
\hline 39 & Chiliadenus iphionoides & Compositae & Goldy Locks & $\mathrm{P}$ & September-November \\
\hline 40 & Crupina crupinastrum & Compositae & False Saw-wort & $N \& P$ & March-May \\
\hline 41 & Onopordum alexandrinum & Compositae & Thistle & $N \& P$ & March-May \\
\hline 42 & Onopordum blancheanum & Compositae & Cotton Thistle & $P \& N$ & March-June \\
\hline 43 & Onopordum carduiforme & Compositae & False Plumed Thistle & $N \& P$ & March-June \\
\hline 44 & Onopordum cynarocephalum & Compositae & Artichoke Cotton-Thistle & $N \& P$ & May-July \\
\hline 45 & Senecio joppensis & Compositae & Jaffa Groundsel & $P \& N$ & January-April \\
\hline 46 & Senecio vernalis & Compositae & spring Groundsel & $P \& N$ & January-December \\
\hline 47 & Silybum marianum & Compositae & Milk Thistle & $N \& P$ & March-May \\
\hline 48 & Cynara syriaca & Compositae & Syrian Artichoke & $N \& P$ & June-August \\
\hline
\end{tabular}


(Annex 1 continued)

\begin{tabular}{|c|c|c|c|c|c|}
\hline No. & Spp. scientific name & Family name & Spp. English name & Food elements & Blooming months \\
\hline 49 & Dittrichia graveolens & Compositae & Stinkwort & P \& N & August-December \\
\hline 50 & Dittrichia viscosa & Compositae & Inula & $P \& N$ & September-November \\
\hline 51 & Echinops gaillardotii & Compositae & Globe Thistle & N \& P & June-July \\
\hline 52 & Echinops philistaeus & Compositae & Pale Globe Thistle & N \& P & May-August \\
\hline 53 & Eupatorium cannabinum & Compositae & Common Hemp Agrimony & $P \& N$ & June October \\
\hline 54 & Notobasis syriaca & Compositae & Syrian Thistle & $N \& P$ & April-June \\
\hline 55 & Convolvulus althaeoides & Convolvulaceae & Mallow Bindweed & $\mathrm{N}$ & March-June \\
\hline 56 & Convolvulus dorycnium & Convolvulaceae & Splendid Bindweed & $\mathrm{N}$ & April-July \\
\hline 57 & Diplotaxis erucoides & Cruciferae & White Wall-rocket & $\mathrm{N}$ & $\begin{array}{l}\text { February-March, } \\
\text { November-December }\end{array}$ \\
\hline 58 & Diplotaxis harra & Cruciferae & Wall-rocket & $\mathrm{N}$ & January-May \\
\hline 59 & Eruca sativa & Cruciferae & Arugula & $P \& N$ & February-May \\
\hline 60 & Maresia pulchella & Cruciferae & Pretty Maresia & $P \& N$ & January-November \\
\hline 61 & Sinapis alba & Cruciferae & White Mustard & $P \& N$ & January-December \\
\hline 62 & Sinapis arvensis & Cruciferae & Charlock & $P \& N$ & March-May \\
\hline 63 & Zilla spinosa & Cruciferae & Spiny Zilla & $\mathrm{N}$ & January-May \\
\hline 64 & Raphanus raphanistrum & Cruciferae & Sea-Radish, White Charlock & $\mathrm{N}$ & January-May \\
\hline 65 & Ecballium elaterium & Cucurbitaceae & Squirting Cucumber & N \& P & May-October \\
\hline 66 & Cephalaria joppensis & Dipsacaceae & Jaffa Scabious & $P \& N$ & May-September \\
\hline 67 & Arbutus andrachne & Ericaceae & Eastern Strawberry Tree & $\mathrm{N}$ & March-April \\
\hline 68 & Lupinus pilosus & Fabaceae & Blue Lupine & $\mathrm{P}$ & February-April \\
\hline 69 & Prosopis farcta & Fabaceae & Prosopis & $P \& N$ & May-August \\
\hline 70 & Lotus collinus & Fabaceae & Judean Bird’s-foot Trefoil & $P \& N$ & March-May \\
\hline 71 & Lotus creticus & Fabaceae & Silvery Bird's-foot Trefoil & $P \& N$ & March-August \\
\hline 72 & Lupinus palaestinus & Fabaceae & Palestine Lupine & $\mathrm{P}$ & February-May \\
\hline 73 & Medicago sativa & Fabaceae & Buffalo Herb & $P \& N$ & April-July \\
\hline 74 & Melilotus albus & Fabaceae & Yellow Melilot & $N \& P$ & April-October \\
\hline 75 & Hypericum triquetrifolium & Gluciaceae & Tumble St. John’s-wort & $\mathrm{P}$ & May-September \\
\hline 76 & Moluccella laevis & Labiatae & $\begin{array}{l}\text { Molucca Balm; Shell } \\
\text { Flower; Bells of Ireland }\end{array}$ & $\mathrm{N}$ & April-July \\
\hline 77 & Origanum syriacum & Labiatae & The Rose of Jericho & N \& P & January-September \\
\hline 78 & Ballota undulata & Lamiaceae & Common Ballota & $\mathrm{N}$ & April-October \\
\hline 79 & Coridothymus capitatus & Lamiaceae & Cone Head Thyme & $P \& N$ & May-October \\
\hline 80 & Lamium moschatum & Lamiaceae & Musky Archange & $\mathrm{N}$ & March-April \\
\hline 81 & Lavandula stoechas & Lamiaceae & $\begin{array}{l}\text { French Lavender; Spanish } \\
\text { Lavender }\end{array}$ & $\mathrm{N}$ & February-May \\
\hline 82 & Mentha sp. & Lamiaceae & Mint & $\mathrm{N}$ & June-July \\
\hline 83 & Micromeria fruticosa & Lamiaceae & White Leaved Savory & $P \& N$ & February-June \\
\hline 84 & Prasium majus & Lamiaceae & Great Hedge-nettle & $\mathrm{N}$ & July-October \\
\hline 85 & Rosmarinus officinalis & Lamiaceae & Rosemary & $\mathrm{N}$ & March-September \\
\hline 86 & Salvia fruticosa & Lamiaceae & Greek Sage & $\mathrm{N}$ & March-June \\
\hline 87 & Salvia hierosolymitana & Lamiaceae & Jerusalem Sage & $P \& N$ & March-July \\
\hline 88 & Salvia indica & Lamiaceae & Wild Sage & $P \& N$ & April-May \\
\hline 89 & Salvia judaica & Lamiaceae & Judean Sage & $P \& N$ & April-June \\
\hline 90 & Satureja thymbra & Lamiaceae & Savory of Crete & $\mathrm{N}$ & March-July \\
\hline 91 & Sideritis perfoliata & Lamiaceae & Mountain Tea & $\mathrm{N}$ & June-October \\
\hline 92 & Sideritis pullulans & Lamiaceae & Branching Ironwort & $\mathrm{N}$ & May-October \\
\hline 93 & Stachys distans & Lamiaceae & Lamb’s Ear & $\mathrm{N}$ & May-June \\
\hline 94 & Teucrium creticum & Lamiaceae & Cretan Germander & N \& P & May-September \\
\hline
\end{tabular}


(Annex 1 continued)

\begin{tabular}{|c|c|c|c|c|c|}
\hline No. & Spp. scientific name & Family name & Spp. English name & Food elements & Blooming months \\
\hline 95 & Teucrium divaricatum & Lamiaceae & Spreading Germander & P \& N & April-June \\
\hline 96 & Teucrium scordium & Lamiaceae & Water Germander & $P \& N$ & June-October \\
\hline 97 & Trifolium fragiferum & Lamiaceae & Strabwerry Clover & $\mathrm{N}$ & April-May \\
\hline 98 & Trifolium palaestinum & Lamiaceae & Palestine Clover & $P \& N$ & April-May \\
\hline 99 & Trifolium purpureum & Lamiaceae & Purple Clover & $P \& N$ & April-May \\
\hline 100 & Trifolium repens & Lamiaceae & Dutch Clover & $\mathrm{N}$ & April-May \\
\hline 101 & Trifolium resupinatum & Lamiaceae & Trifolium Pink Clover & $\mathrm{N}$ & April-May \\
\hline 102 & Urginea maritima & Liliaceae & Sea-squill & $P \& N$ & July-October \\
\hline 103 & Alcea dissecta & Malvaceae & Bristly Hollyhock & $P \& N$ & April-July \\
\hline 104 & Alcea setosa & Malvaceae & Hollyhock & $P \& N$ & April-June \\
\hline 105 & Eucalyptus sp. & Myrtaceae & Eucalyptus & $\mathrm{N}$ & $\begin{array}{l}\text { February-May, } \\
\text { August-December }\end{array}$ \\
\hline 106 & Glaucium flavum & Papaveraceae & Yellow-horned Poppy & $\mathrm{P}$ & April-August \\
\hline 107 & Glaucium grandiflorum & Papaveraceae & Red-horned Poppy & $\mathrm{P}$ & April-May \\
\hline 108 & Anagyris foetida & Papilionaceae & Mediterranean Stinkbush & $\mathrm{P}$ & January-April \\
\hline 109 & Ononis alopecuroides & Papilionaceae & Foxtail Rest Harrow & $\mathrm{P}$ & April-May \\
\hline 110 & Ononis hirta & Papilionaceae & Hairy Rest Harrow & $\mathrm{P}$ & March-May \\
\hline 111 & Ononis natrix & Papilionaceae & Sticky Rest Harrow & $\mathrm{P}$ & April-September \\
\hline 112 & Ononis pubescens & Papilionaceae & Downy Rest Harrow & $\mathrm{P}$ & March-July \\
\hline 113 & Retama raetam & Papilionaceae & White Broom & N \& P & March-April \\
\hline 114 & Calligonum comosum & Polygonaceae & Calligonum Fringed & N \& P & February-April \\
\hline 115 & Anemone coronaria & Ranunculaceae & Crown Anemone & $\mathrm{P}$ & February - May \\
\hline 116 & Clematis cirrhosa & Ranunculaceae & Virgin’s Bower & $P \& N$ & November-February \\
\hline 117 & Clematis flammula & Ranunculaceae & Sweet Virgin’s Bower & $P \& N$ & April-June \\
\hline 118 & Reseda alba & Resedaceae & White Upright Mignonette & $P \& N$ & February-April \\
\hline 119 & Reseda boissieri & Resedaceae & Mignonette & $P \& N$ & February-May \\
\hline 120 & Reseda decursiva & Resedaceae & Mignonette & $P \& N$ & February-November \\
\hline 121 & Reseda lutea & Resedaceae & Yellow Mignonette & $P \& N$ & March-June \\
\hline 122 & Reseda muricata & Resedaceae & Mignonette & $P \& N$ & March-April \\
\hline 123 & Reseda orientalis & Resedaceae & Oriental Mignonette & $P \& N$ & December-February \\
\hline 124 & Rhamnus lycioides & Rhamnaceae & Palestine Buckthorn & $P \& N$ & January-April \\
\hline 125 & Ziziphus spina-christi & Rhamnaceae & Christ’s Thorn Jujube & $P \& N$ & April-October \\
\hline 126 & Amygdalus communis & Rosaceae & Common Bitter Almond & $P \& N$ & February-March \\
\hline 127 & Amygdalus korschinskii & Rosaceae & Wild Almond & $P \& N$ & February-March \\
\hline 128 & Amygdalus sp. & Rosaceae & Almond & $P \& N$ & February -March \\
\hline 129 & Prunus avium & Rosaceae & Sweet Cherry & $P \& N$ & March-April \\
\hline 130 & Prunus domestica & Rosaceae & Plum & $P \& N$ & March-April \\
\hline 131 & Prunus persica & Rosaceae & Peach & $P \& N$ & March-April \\
\hline 132 & Prunus ursina & Rosaceae & Bear's Plum & $P \& N$ & March-April \\
\hline 133 & Citrus spp. & Rutaceae & Lemon & $P \& N$ & April-June \\
\hline 134 & Salix alba & Salicaceae & Willow & $P \& N$ & March-June \\
\hline 135 & Verbascum galilaeum & Scrophulariaceae & Common Mullein & $\mathrm{P}$ & April-July \\
\hline 136 & Verbascum sinaiticum & Scrophulariaceae & Sinai Mullein & $\mathrm{P}$ & April-July \\
\hline 137 & Verbascum sinuatum & Scrophulariaceae & Scallop-leaved Mullein & $\mathrm{P}$ & April-October \\
\hline 138 & Styrax officinalis & Styracaceae & Storax Tree & N \& P & March-April \\
\hline 139 & Tamarix aphylla & Tamaricaceae & Athel Pine & $P \& N$ & July-November \\
\hline 140 & Tamarix tetragyna & Tamaricaceae & Tamarisk & $P \& N$ & March-May \\
\hline 141 & Phyla nodiflora & Verbenaceae & Sawtooth Fogfruit & $\mathrm{N}$ & April-September \\
\hline 142 & Nitraria retusa & Zygophyllaceae & Salt Tree & $P \& N$ & April-May \\
\hline 143 & Zygophyllum dumosum & Zygophyllaceae & Bushy Bean Caper Plant & $P \& N$ & February-April \\
\hline
\end{tabular}

$\mathrm{P}=$ pollen and $\mathrm{N}=$ nectar. 